\title{
Evaluation of Response Rate to Resynchronization Therapy: the Super-Responder
}

\author{
Avaliação da Taxa de Resposta à Terapia de Ressincronização: \\ o Super-Respondedor \\ Izaias Marques de Sa Junior ${ }^{1, *}$, Jose Carlos Pachon Mateos ${ }^{1,2}$, Juan Carlos Pachón Mateos ${ }^{1,2}$, \\ Remy Nelson Albornoz Vargas ${ }^{1,2}$
}

ORCID IDs

Sa Junior IM (DD https://orcid.org/0000-0002-6689-4102

\begin{abstract}
Cardiac resynchronization therapy (CRT) emerged as a therapeutic modality for patients with cardiac insufficiency $(\mathrm{Cl})$ refractory to pharmacological treatment. Over the last 20 years, several clinical studies have sought to establish their benefits in different populations. The review of the results of these studies has shown that in patients with advanced Cl (functional class (FC) I, II, III and IV of the New York Heart Association (NYHA) CRT produces consistent improvements in quality of life, FC and exercise capacity, as well as reducing hospitalizations and mortality rates. Up to $70 \%$ of patients submitted to CRT evolve as responders. The criteria adopted in the evaluation of the CRT response rate will be elucidated in this article, in which the main objective is to highlight the concept of the CRT super-responder.
\end{abstract}

KEYWORDS: Cardiac resynchronization therapy; Respondent; Super-responders.

\section{RESUMO}

A terapia de ressincronização cardíaca (TRC) surgiu como modalidade terapêutica para pacientes com insuficiência cardíaca (IC) refratária ao tratamento farmacológico. Ao longo dos últimos 20 anos, vários estudos clínicos buscaram estabelecer seus benefícios em diferentes populações. A revisão dos resultados desses estudos demonstrou que em pacientes com IC avançada [classes funcionais (CFs) I, II, III e IV da New York Heart Association (NYHA)] a TRC produz melhorias consistentes para a qualidade de vida, CF e capacidade de exercício, além de reduzir as hospitalizações e a taxa de mortalidade. Até $70 \%$ dos pacientes submetidos à TRC evoluem como respondedores. Os critérios adotados na avaliação da taxa de resposta à TRC serão elucidados neste artigo, no qual o objetivo maior é ressaltar o conceito do super-respondedor à TRC.

PALAVRAS-CHAVE: Terapia de ressincronização cardíaca; Respondedor; Super-repondedores.

1. Instituto Dante Pazzanese de Cardiologia - São Paulo/SP - Brazil.

2.Associação do Sanatório Sírio - Hospital do Coração - Setor de Eletrofisiologia - São Paulo/SP - Brazil.

*Correspondence author: izaiasdesa@gmail.com

Received: 24 Oct 2016 | Accepted: 07 Jul 2017

Section Editor: Genildo Ferreira Nunes 


\section{INTRODUCTION}

Cardiac insufficiency (CI) represents a major public health problem worldwide. In Europe and the United States, it represents an important cause of hospitalization in patients aged 65 and over ${ }^{1,2}$. This disease has a great social, economic and, above all, human impact, since it imposes important physical limitations on patients, resulting in early retirements, with high governmental costs ${ }^{3}$.

Despite advances in available pharmacological therapies, they do not fully meet the needs of patients with heart failure ${ }^{4}$. Non-pharmacological therapies, such as mechanical left ventricular assist devices and cardiac transplantation, are reserved for a small group of patients with $\mathrm{CI}^{5,6}$. In addition to these, cardiac resynchronization therapy (CRT) and implantable cardioverter defibrillators appeared as a good option for patients with CI refractory to drug treatment $t^{4-7}$.

The pathophysiological basis of CRT is the presence of dyssynchrony associated with conduction disturbance. With the implantation of electrodes in the right atrium (RA), left ventricle (LV) and right ventricle (RV) and adequate device programming, atrioventricular and ventricle-ventricular resynchronization would be achieved and expected patient improvement. CRT is indicated in patients with $\mathrm{CI}$ with conduction disorder, mainly with left bundle branch block morphology (LBBB), functional classes (FC) II, III, IV NYHA, and optimized clinical treatment ${ }^{8,9}$.

The CRT response rate historically approaches $70 \%$ of cases. With improved patient selection, ie QRS duration> $150 \mathrm{~ms}$ and LBBB morphology $\mathrm{y}^{10}$, absence of fibrosis by magnetic resonance imaging (MRI) in the posterolateral region ${ }^{11}$, as well as total fibrosis load $<20 \%{ }^{12}$, improvement of the surgical technique, adequate programming of the device, a recent and considerable increase in the response rate to CRT was observed.

The following is the case of a patient considered to be a CRT super-responder. We will also discuss the important variables in the selection of these patients, as well as the criteria to be considered super-responders.

\section{CASE REPORT}

MJS, 72 years old, born in the state of Paraíba, a patient with CI since 2010, without other comorbidities.
Admitted in a tertiary hospital in 2015 for optimization and investigation of $\mathrm{CI}$ etiology.

In this period, FC III, doses of carvedilol, enalapril, and furosemide were optimized. The patient had a significant improvement in FC, now FC II. All the necessary exams were done to elucidate the etiology of CI (Chagas, echocardiogram, MRI of the heart, myocardial scintigraphy), and, as definitive diagnosis, idiopathic CI.

Because he was an LBBB patient and still symptomatic despite clinical treatment, he was referred to the pacemaker team to decide on CRT. Based on the current evidence, we opted for the implantation of the cardiac resynchronizer, performed 12/13/2015.

Five essential steps for success in using CRT as a treatment modality were defined. They were followed strictly.

\section{Patient selection}

According to the current evidence, $\mathrm{HF}$ with ejection fraction $<35 \%$ and LBBB with QRS duration $>150$ ms may be one of the only indications considered to be FC IA de $\mathrm{CRT}^{8,9}$. In the present case, those criteria were satisfied.

\section{Surgical technique}

The cardiac dyssynchrony generated by LBBB has the slowest and most delayed region on the conduction in the posterolateral wall of the $\mathrm{LV}^{13}$. This should be the implant site of the LV electrode. The cardiac vein of choice should be the one that is directed to the posterolateral region of the LV (Fig. 1). In addition, performing an MRI of the pre-implanted heart discards the presence of fibrosis in this region, thus avoiding possible stimulation in a non-viable region ${ }^{11}$. In the present case, all such care was observed.

\section{X-ray and comparison of electroencephalograms (ECGs) (<one month postoperatively)}

The correct position of the electrodes, especially the LV coronary sinus electrode, can be verified in the posterolateral region (Fig. 2). In the case of a dislocation, it should be surgically resubmitted for repositioning. In the present case, the LV electrode was stable in the postoperative period.

In addition, a considerable reduction in pre and postimplant QRS duration provides good prospects regarding 
the chances of responding to CRT (Fig. 3). In the present case, there was an $18.75 \%$ reduction in QRS duration.

\section{Proper Resynchronizer Programming}

Biventricular pacing should be confirmed (> 90\% capture by telemetry, ideally $100 \%)^{14}$ (Fig. 4), as well as the stimulation thresholds. Special attention is given to other factors that reduce the CRT response, such as the presence of atrial fibrillation and frequent ventricular extrasystoles and others associated with worsening of the quality of life, namely phrenic stimulation (absent in the case reported).

It is suggested that the atrioventricular interval (AVI) be adjusted around $120 \mathrm{~ms}^{15}$ (Fig. 5). The programming of the pacing interval between the ventricles (VV) should be the one in which the lowest QRS is produced in biventricular pacing on the 12-lead ECG, in general, VV interval programmed between $0 \mathrm{~ms}$ or $-30 \mathrm{~ms} L V>R V 5$ ). In the present case, these concepts were adopted.

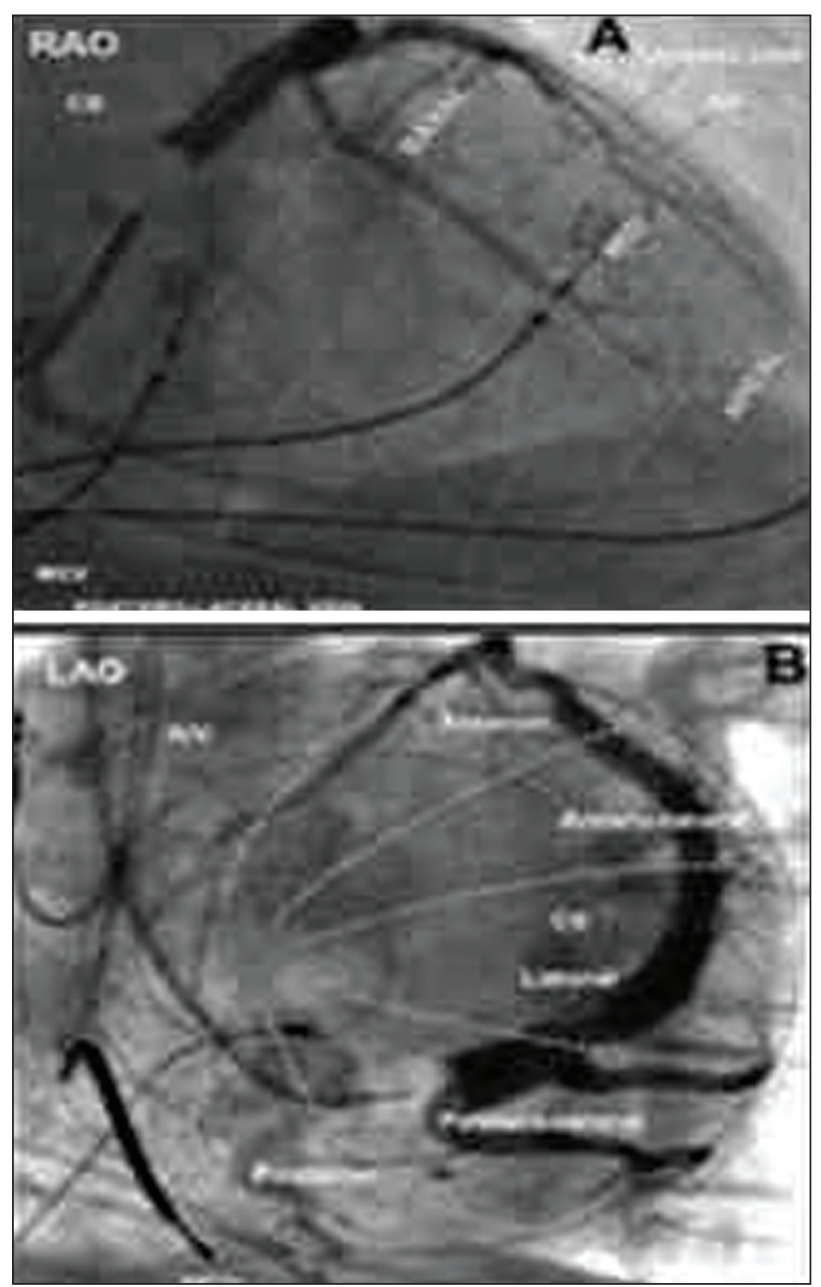

Figure 1. Coronary sinus anatomy.
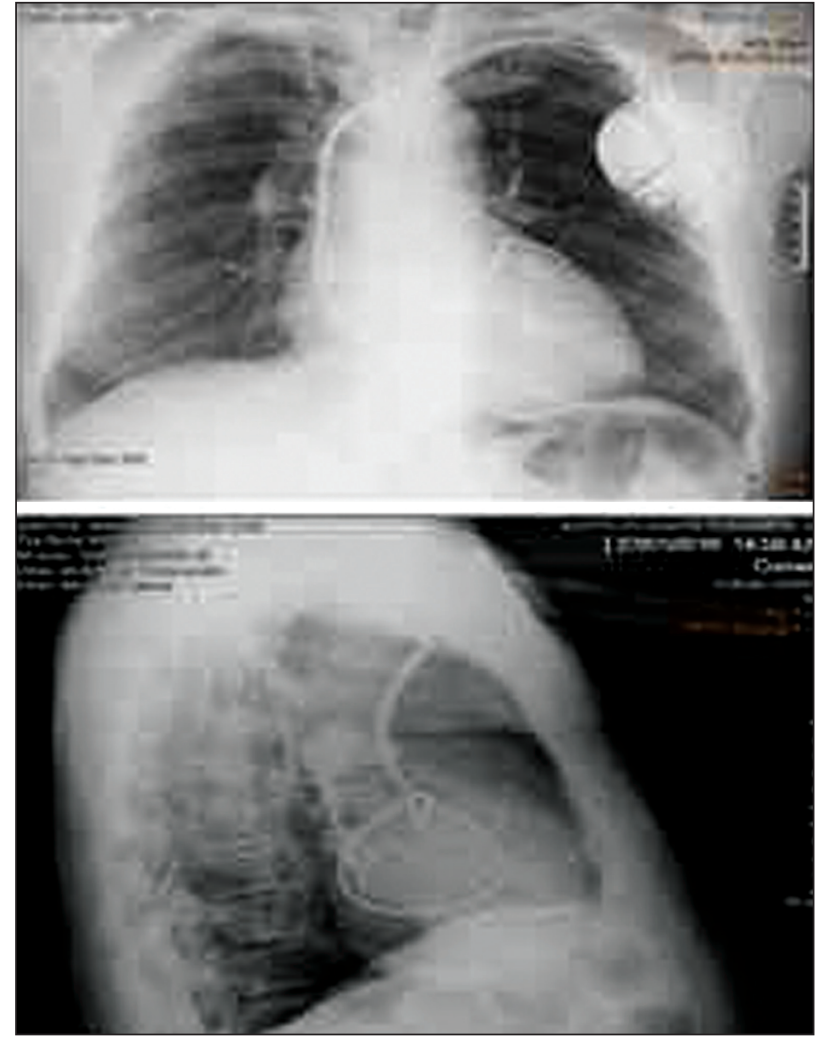

Figure 2. Electrodeposition LV posterolateral wall.
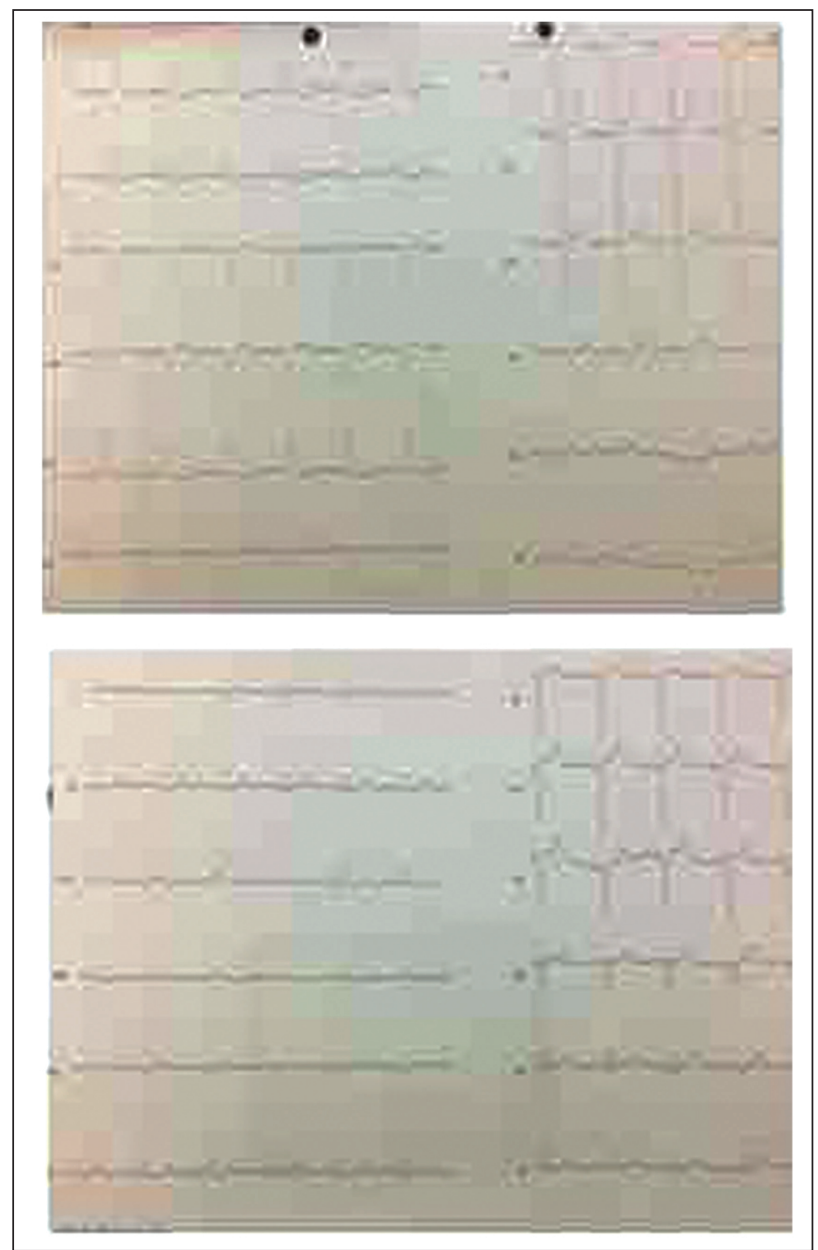

Figure 3. (a) Pre-ECG and (b) post-implantation ECG. 


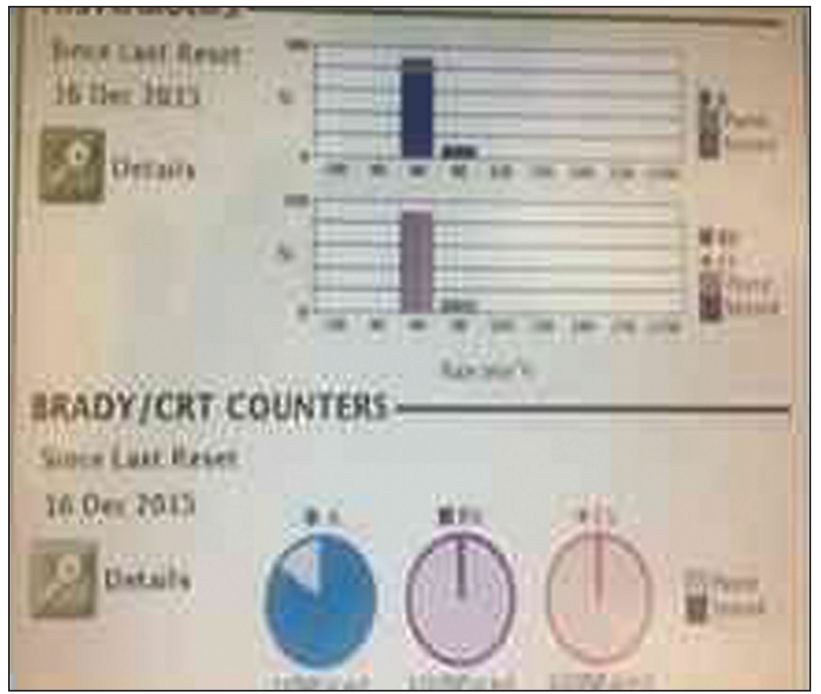

Figure 4. 100\% LV capture.

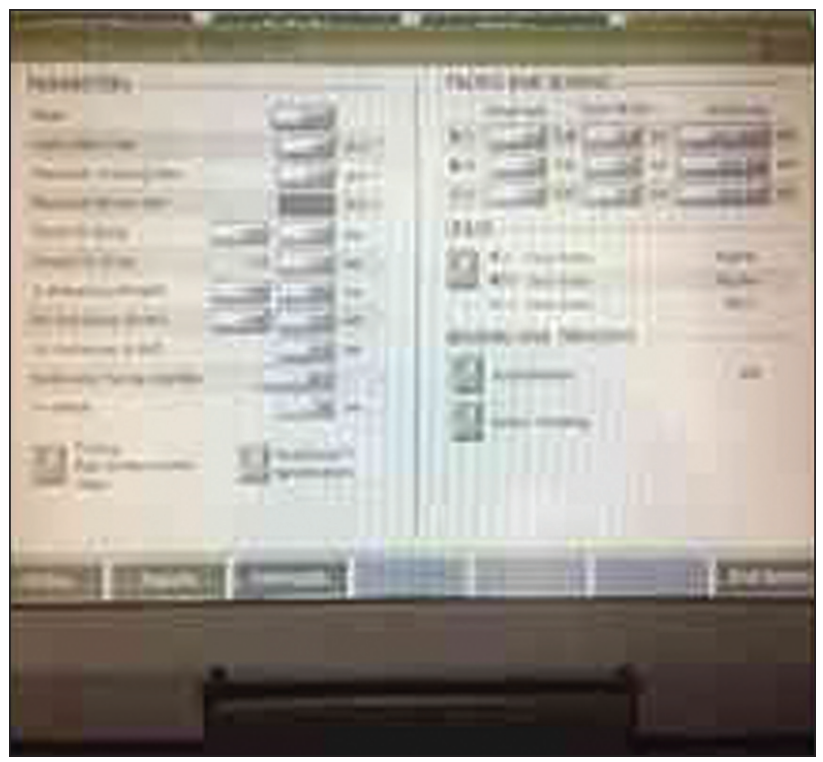

Figure 5. IAV 120MS and VV-30MS.

\section{Evaluation of the CRT response rate}

Finally, it will be assessed whether our patient actually responded to CRT. According to the main studies, six months would be enough time to have this answer. By means of clinical (FC), echocardiographic criteria [ventricular function (VF), end-systolic volume (ESV)] and others we can conclude about this. In the present case, after evaluation, it was concluded that it is a super-responder. From the echocardiographic data, the VF of $28 \%$ was $55 \%$ (normalization), the ESV from 173 to $79 \mathrm{~mL}$, a reduction of $54.4 \%$, reaching LV reverse remodeling. Finally, FC II was for NYHA FC I, remaining practically asymptomatic.

\section{DISCUSSION}

\section{Concept of super-responder to CRT}

Patients without structural heart disease and with LBBB when compared to those without structural heart disease and without $\mathrm{LBBB}$ present, on average, $7 \%$ less of the VF, considering both within the range of normality ${ }^{16}$. In about three years, approximately $16 \%$ of patients with normal heart and LBBB may develop with $\mathrm{CI}^{17}$. This condition will be defined as a primary electrical cardiopathy ${ }^{18-20}$.

When we work on the cause of heart disease in question, we generally have the best rates of response to treatment. It is believed that these patients are the ones with the highest CRT response rate - the super-responders. It is clear that many other patients, with the most diverse etiologies of CI, can progress with LBBB and benefit from CRT, but it is believed that response rates are more modest.

Although there was no consensus regarding the best criterion to be considered in the evaluation of CRT response rate, clinical parameters with improvement of at least one of the FC NYHA, 10 to $15 \%$ increase in the sixminute walk test, elevation of 10 to $15 \%$ of peak oxygen consumption (VO2 peak) in ergospirometry, improvement of the Minnesota life questionnaire, and echocardiographic findings, such as improvement of LVEF $>5 \%$ and reduction of ESV greater than 10 to $15 \%$, are the most used. Other criteria, such as improved blood pressure and natriuretic peptide reduction, may also be considered.

Likewise, because there is no consensus in the medical literature regarding the concept of the super-responder, some of the main echocardiographic criteria used in the large studies on the subject are listed in Table 1.

Table 1. Parameters and cut-off points used in the superresponder definition.

\begin{tabular}{|c|c|}
\hline Parameters & Cut-Off points \\
\hline Ventricular Function ${ }^{19}$ & $>50 \%$ and functional recovery \\
\hline Ventricular Function ${ }^{20}$ & $\begin{array}{c}>2 \times \text { the baseline function or }>45 \% \\
\text { and }>1 \text { Functional Class NYHA }\end{array}$ \\
\hline End-Systolic Volume 21 & Reduction > 30\% \\
\hline End-Dyastolic Volume ${ }^{21}$ & Reduction $>20 \%$ \\
\hline Ventricular Function ${ }^{21}$ & Increase $>10 \%$ \\
\hline Volume Sistólico Final22 & Reduction > 30\% \\
\hline Ventricular Function ${ }^{23}$ & $\begin{array}{l}>50 \% \text {, reduction End-Systolic Volume } \\
>25 \% \text { and }>1 \text { Functional class NYHA }\end{array}$ \\
\hline Ventricular Function ${ }^{24}$ & Increase $>20 \%$ \\
\hline
\end{tabular}

Source: Adapted from Steffel e Ruschitzka25; NYHA = New York Heart Association 


\section{CONCLUSION}

An increasing selection of CRT candidates, correct surgical technique, adequate device programming, and regular follow-up have all contributed to the increased CRT response rate. In this context, the super-responder concept stands out. In the case reported here, we elucidate that when the approach to CRT is systematized, it approaches more and more of the super-responders, thus achieving the best results that this modality of treatment can provide.

\section{AUTHORS' CONTRIBUTION}

All the authors contributed equally to this article.

\section{REFERENCES}

1. Rich MW. Heart failure in the 21st century: a cardiogeriatric syndrome. J Gerontol A. 2001;56(2):8896.

2. Krum H, Gilbert RE. Demographics and concomitant disorders in heart failure. Lancet. 2003;362:147-58. https://doi.org/10.1016/S0140-6736(03)13869-X

3. Bui AL, Horwich TB, Fonarow GC. Epidemiology and risk profile of heart failure. Nat Rev Cardiol. 2011;8(1):30-41. https://doi.org/10.1038/nrcardio.2010.165

4. Linde C, Ellenbogen K, Mcalister FA. Cardiac resynchronization therapy (CRT): clinical trial, guidelines, and target populations. Heart Rhytm. 2012;8 Suppl:S3-13. https://doi.org/10.1016/j.hrthm.2012.04.026

5. Salerno HD, Oliveira JC, Melo CS, Lage JS. Evidências atuais para indicação de cardioversores-desfibriladores implantáveis e ressincronizadores cardíacos. In: Melo CS, editor. Temas de marcapasso. 2a ed. São Paulo: Leitura Médica; 2011. p 515-31.

6. Bocchi EA, Marcondes-Braga FA, Bacal F, Ferraz AS, Albuquerque D, Rodrigues DA, et al. Atualização da diretriz brasileira de insuficiência cardíaca crônica 2012. Arq Bras Cardiol. 2012;8 Suppl:S1-33. https://doi. org/10.5935/abc.20120101

7. McMurray JJV, Adamopoulos S, Anker SD, Auricchio A, Bohm M, Dickstein K, et al. ESC Guidelines for the diagnosis and treatment of acute and chronic heart failure. Eur Heart J. 2012;33:1787-847. https://doi. org/10.1093/eurheartj/ehs104

8. European Society of Cardiology (ESC), European Heart Rhythm Association (EHRA), Brignole M, Auricchio A, Baron-Esquivias G, Bordachar P, et al. 2013 ESC guidelines on cardiac pacing and cardiac resynchronization therapy: the task force on cardiac pacing and resynchronization therapy of the European Society of Cardiology (ESC). Developed in collaboration with the European Heart Rhythm Association (EHRA). Europace. 2013;15(8):1070118. https://doi.org/10.1093/europace/eut206

9. Writing Committee Members, Yancy CW, Jessup $M_{\text {, }}$ Bozkurt B, Butler J, Casey Junior DE, et al. American College of Cardiology Foundation/American Heart Association Task Force on Practice Guidelines. 2013 ACCF/AHA guideline for the management of heart failure: a report of the American College of Cardiology Foundation/American Heart Association Task Force on practice guidelines. Circulation. 2013;128(16):e240-327. https://doi.org/10.1161/CIR.0b013e31829e877610

10. Poole JE, Singh JP, Birgersdotter-Green U. QRS duration or QRS morphology. What really matters in cardiac resynchronization therapy? JACC. 2016;67(9):1104-17. https://doi.org/10.1016/j.jacc.2015.12.039

11. Bleeker GB, Kaandorp TA, Lamb HJ, Boersma E, Steendijk $P$, et al. Effect of posterolateral scar tissue on clinical and echocardiographic improvement after cardiac resynchronization therapy. Circulation. 2006;113:96976. https://doi.org/10.1161/circulationaha.105.543678

12. Ypenburg C, Roes SD, Bleeker GB, Kaandorp TA, Roos A de, Schalij MJ, et al. Effect of total scar burden on contrast-enhanced magnetic resonance imaging on response to cardiac resynchronization therapy Am J Cardiol. 2007;99(5):657-60. https://doi.org/10.1016/j. amjcard.2006.09.115

13. Leyva F, Nisam S, Auricchio A. 20 years of cardiac resynchronization therapy. JACC. 2014;64(10):1047-58. https://doi.org/10.1016/j.jacc.2014.06.1178

14. Lubitz SA, Singh JP. Biventricular pacing: more is better! Eur Heart J. 2015;36(7):407-9. https://doi.org/10.1093/ eurheartj/ehu347

15. Brenyo A, Kutyifa $V$, Moss AJ, Mathias A, Barsheshet A, Pouleur A-C, et al. Atrioventricular delay programming and the benefit of cardiac resynchronization therapy in MADIT-CRT. Heart Rhyth. 2013;10(8):1101-1248. https:// doi.org/10.1016/j.hrthm.2013.04.013

16. Grines CL, Bashore TM, Boudoulas H, Olson S, Shafer $P$, Wooley CF. Functional abnormalities in isolated left bundle branch block the effect of interventricular asynchrony. Circulation. 1989;79:845-53.

17. Angheloiu GO, Saul M, Edelman K, Shah H, Mezu UL, Saba S. Predictors of left ventricular function deterioration in patients with left bundle branch block and ejection fraction > 50\%. Congest Heart Fail. 2013;19(4):E1-4. https://doi.org/10.1111/chf.12028

18. Blanc JJ, Fatemi M, Bertault V, Baraket F, Etienne Y. Evaluation of left bundle branch block as a reversible cause of non-ischemic dilated cardiomyopathy with severe heart failure. A new concept of left ventricular dyssynchrony-induced cardiomyopathy. Europace. 2005;7:604-10. https://doi.org/10.1016/j. eupc.2005.06.005 
19. Castellant P, Fatemi M, Orhan E, Etienne Y, Blanc JJ. Patients with non-ischaemic dilated cardiomyopathy and hyper-responders to cardiac resynchronization therapy: characteristics and long-term evolution. Europace. 2009;11(3):350-5. https://doi.org/10.1093/europace/ eup035.

20. Antonio N, Teixeira R, Coelho L, Lourenço C, Monteiro $\mathrm{P}$, Ventura $\mathrm{M}$, et al. Identification of 'super-responders' to cardiac resynchronization therapy: the importance of symptom duration and left ventricular geometry. Europace. 2009;11(3):343-9. https://doi.org/10.1093/ europace/eup038

21. Steffel J, Milosevic G, Hürlimann A, Krasniqi, Namdar M, Ruschitzka F, et al. Characteristics and long-term outcome of echocardiographic super-responders to cardiac resynchronisation therapy: 'real world' experience from a single tertiary care centre. Heart. 2011;97(20):166874. https://doi.org/ 0.1136/heartjnl-2011-300222
22. Ypenburg C, van Bommel RJ, Borleffs CJ, Bleeker GB, Boersma E, Schalij MJ, et al. Long-term prognosis after cardiac resynchronization therapy is related to the extent of left ventricular reverse remodeling at midterm follow- up. J Am Coll Cardiol. 2009;53(6)483-90. https:// doi.org/10.1016/j.jacc.2008.10.032

23. Reant $P$, Zaroui A, Donal E, Mignot A, Bordachar $P$, Deplagne $A$, et al. Identification and characterization of super-responders after cardiac resynchronization therapy. Am J Cardiol. 2010;105(9):1327-35. https://doi. org/10.1016/j.amjcard.2009.12.058

24. Rickard J, Kumbhani DJ, Popovic Z, Verhaert D, Manne M, Sraow D, et al. Characterization of superresponse to cardiac resynchronization therapy. Heart Rhythm. 2010;(7):885-9. https://doi.org/10.1016/j. hrthm.2010.04.005

25. Steffel J; Ruschitzka F. Superresponse to cardiac resynchronization therapy. Circulation. 2014;130(1):8790. https://doi.org/10.1161/circulationaha.113.006124 